\title{
CHALLENGES OF STAY-AT-HOME POLICY IMPLEMENTATION DURING THE CORONAVIRUS (COVID-19) PANDEMIC IN INDONESIA
}

\author{
Tantangan Implementasi Kebijakan Tetap Di Rumah Selama Pandemi \\ Virus Corona (COVID-19) di Indonesia \\ ${ }^{*}$ Febri Endra Budi Setyawan', Retno Lestari ${ }^{2}$ \\ ${ }^{1}$ Department of Family, Industrial and Islamic Medical Sciences, Faculty of Medicine, University of Muhammadiyah \\ Malang, Indonesia \\ ${ }^{2}$ Study Program of Nursing Science, Faculty of Medicine, University of Brawijaya, Indonesia \\ ${ }^{\star}$ Correspondence: febri@umm.ac.id
}

\begin{abstract}
Received: 25 April 2020
The coronavirus disease 2019 (COVID-19) has been labelled as a global pandemic disease by the World Health Organization. The number of infections in Indonesia rose significantly to 8211 cases, and 689 coronavirus deaths were reported on April 24 $4^{\text {th }}, 2020$ (CNN Indonesia, 2020). We knew that the Indonesian Government has made numerous strategies to control the spread of infection in our community, but implementation plans were limited in addressing the challenges of stay-at-home policy. These challenges may include economic impact due to COVID-19, struggles for work-from-home, and leaders' ability to influence the society.
\end{abstract}

\section{Economic Impact due to COVID-19}

On March $16^{\text {th }}, 2020$, the Ministry of Administrative and Bureaucratic Reform announced new regulations for controlling the spread of COVID-19 in the community. These regulations explained about the instructions to stay-at-home or work-fromhome during the COVID-19 outbreak (Ministry of Administrative and Bureaucratic Reform, 2020). All employees were encouraged to work from home unless they had to be in public areas for reasonable excuses.

Among 273 million of Indonesians instructed to stay-at-home, a major impact

may strike the Indonesian economy beyond the spread of the COVID-19 itself (World Population Review, 2020). As a developing country, Indonesia has 760 thousands of self-employed workers who should continue to work outside their home (Abdila, 2020). Although some selfemployed workers can create a functional working space at home, they still need financial security which perhaps cannot be as much as when they work outside. Meanwhile, this social distancing regulation has affected many people especially who have to work outside, and thus they become unemployed for a lot of reasons (Nikola, 2020). It was reported 1.9 million of Indonesian people have lost their jobs due to weak management crisis during this pandemic (Shalilah, 2020).

Therefore, addressing the economic impact of COVID-19 could be done through stay-at-home practice. In addition to this, incentives and rewards shall be prepared to protecteconomic activity (Fenichel, 2013). Lately, Indonesian Government also provided social security program for those affected by COVID-19. The Government released Family Hope Program (Rp. 37.4 trillion), Social Assistance for Staple Food (Rp. 2.2 trillion), Village Fund (Rp. 21 trillion), Cash Labor-Intensive Program (Rp. 16.9 trillion), 
and Pre-Employment Card Program (Rp. 360 billion). These programs were expected to assist the community to manage the economic impact due to COVID-19 (Secretariat of the Republic of Indonesia, 2020).

\section{Struggles for Work-From-Home}

During the COVID-19 pandemic, many employers have recommended their staffs to work-from-home. Some employees are happier to work at home as they have already been familiar with multimedia technology to effectively communicate with other employees and employers. Zaenudin (2019) explained that there were still $36 \%$ of Indonesians who could not use technology. Additionally, a previous study by Flores (2019) reported that more than half of employees realized that fostering collaboration with co-workers during workfrom-home can be challenging since they have difficulties in separating work-life and home-life.

\section{Leaders' Influence}

The Indonesian Government has already taken numerous strategies to combat COVID-19, such as contact tracing, rapid tests, and adequate treatments. These strategies worked better particularly at regional level than central government level. The central government was indecisive with the situations and made decisions too late, and thus the COVID-19 spreaded so fast (The Jakarta Post, 2020). Consequently, leaders who can make a quick and firm decision with regards to tackling the COVID-19 pandemic. Karakostas and Zizzo (2016) studied factors related to compliance and authority power. They found that pressures from the management could increase the compliance rate by up to $70 \%$. Power could advance the compliance culture among the society.

\section{Overcoming Challenges of Stay-At- Home Policy}

Nowadays, people have become more and more aware of their health, but icoordination that goes beyond our communities has to be strengthened. The importance of stay-at-home policy has to be reinforced even though it might become challenges during the coronavirus (COVID-19) outbreak.

Stay-at-home policy implementation has become more complex, but the Government still has chances to manage this policy more effectively. Theory of Compliance Management mentions three C's that support this compliance culture, e.g.,communication, confirmation, and correction. These key components have benefits to boost compliance in maintaining daily activities (Lestari et al., 2015). This 3Cs concept can also be used for managing the implementation plans of stay-at-home policy.

Raising public awareness of COVID19 health issues is not easy as the society may differently interpret the importance of stay-at-home policy for their own health. Therefore, people were urged to follow the Government's advice and instruction about COVID-19 (Abdi, 2020).

Based on its theory, effective communication shall begin at the top-level management (Bussmann et al., 2019; Hu et al., 2012). Many leaders have their own personal traits and they are not necessarily admirable. Indonesia needs more charismatic, knowledgeable, and enthusiastic leaders to deliver informative speeches as a proactive approach to avoid negative impacts of miscommunication and increase the community compliance as well. The public figures can work with people in the community and influence their health 
behaviours to achieve the desired goals (Nikoloski, 2015; Supriyanto et al., 2020). For example, Tri Rismaharani, a charismatic leader from Surabaya City, East Java, can effectively communicate with the society to follow the government advice as trusted information sources. She also tried to reduce stress by providing certain facilities for low-income communities (Yasmin, 2020).

Confirmation of the continuous monitoring program could be done to equally support preventive, promotive, curative, and rehabilitative measurements. For instance, Indonesia Ministry of Health conducted COVID-19 monitoring program in which all societies could see tracing progress and the government work on https://covid-monitoring.kemkes.go.id/

(Indonesian Ministry of Health, 2020). Meanwhile, in Taiwan, planning, monitoring, and evaluation programs were done to control public attitudes and beliefs towards false information via conventional media (newspapers, radios, TVs) and modern media (internet) as communication and dissemination tools. Besides, these conventional and social media were in use to increase public awareness and participation in health. The Taiwanese Government routinely shared transparency data on health issues and updates of the situations on media (Hsu et al., 2017).

Further, correction involves noticing any changes and providing effective complaint management strategies can be taken to evaluate the stay-at-home policy implementation (Lestari et al., 2015). The assessments by Indonesian Government can be planned and coordinated to ensure that the policy is effective to combat COVID-19.

The COVID-19 pandemic has persistently affected all biological, psychological, social, and cultural aspects. The COVID-19 case fatality rate is higher than the flu (Wahyuni, 2020). Until now, there have been still no medicines proven to treat the disease (Gallagher, 2020). Many people were so overwhelmed by the abundance of stressing information from social media and internet, which poses a major threat to public mental health. They responded differently from feeling low mood, anxiety, panic attacks and sleep deprivation (Elvira, 2020; Dong and Bouey, 2020). The World Health Organization (2020) provided guidelines to support and prevent people from developing mental health issues, for example, supporting each other to respond the impact of stress due to economic loss during the pandemic. On the other hand, motivation or willingness to comply with the policy was the most important factors for successful policy implementation (Weske et al., 2018).

From what have been explained throughout this article, it can be concluded that compliance with stay-at-home policy management involves the role of top management level and exerts incentives to public. Trusted information and supports are required to maintain the society's mental health and well-being.

\section{CONFLICT OF INTEREST}

The authors declare that there is no conflict of interest regarding the publication of this article.

\section{REFERENCES}

Abdi, A. P. (2020) Menuju Puncak Covid19 di Indonesia, Pemerintah Bisa Apa?, Kesehatan. Available at: https://tirto.id/menuju-puncak-covid19-di-indonesia-pemerintah-bisaapa-eHjM (Accessed: 8 May 2020).

Abdila, R. (2020) Menkop Targetkan Usaha Kecil Naik Kelas dan Jumlah Wirausaha Tumbuh, Tribun Bisnis. 
Available

at:

https://www.tribunnews.com/bisnis/2 020/01/16/menkop-targetkan-usahakecil-naik-kelas-dan-jumlah-

wirausaha-tumbuh (Accessed: 8 May 2020).

Bussmann, K. D. and Niemeczek, A. (2019) 'Compliance Through Company Culture and Values: An International Study Based on the Example of Corruption Prevention', Journal of Business Ethics, 157, pp. 797-811. doi: 10.1007/s10551-0173681-5.

CNN Indonesia (2020) Update Corona 24 April: 8.211 Kasus, 689 Wafat, 1.002 Sembuh, Berita Peristiwa. Available at:

https://www.cnnindonesia.com/nasio nal/20200424122710-20-

496874/update-corona-24-april-

8211-kasus-689-wafat-1002-sembuh (Accessed: 24 April 2020).

Dong, L. and Bouey, J. (2020) 'Public mental health crisis during COVID19 pandemic, China', Emerg Infect Dis, 26(7). Available at: https://doi.org/10.3201/eid2607.2004 07.

Elvira, V. (2020) Cara Mengatasi Stres Akibat Covid-19 dengan Batasi Informasi, Sehat. Available at: https://www.ayobandung.com/read/2 020/05/03/88035/cara-mengatasistres-akibat-covid-19-dengan-batasiinformasi (Accessed: 8 May 2020).

Fenichel, E. P. (2013) 'Economic considerations for social distancing and behavioral based policies during an epidemic', Journal of Health Economics, 32(2), pp. 440-451. doi: 10.1016/j.jhealeco.2013.01.002.

Flores, M. F. (2019) 'Understanding The Challenges Of Remote Working And It's Impact To Workers', International Journal of Business Marketing and Management (IJBMM), 4(11), pp.
40-44.

Gallagher, J. (2020) Coronavirus cure: When will we have a drug to treat it?, Health. Available at: https://www.bbc.com/news/health52354520 (Accessed: 8 May 2020).

Hsu, Y. C. et al. (2017) 'Risk and Outbreak Communication: Lessons from Taiwan's Experiences in the PostSARS Era', Health Security, 15(2), pp. 165-169. doi: 10.1089/hs.2016.0111.

$\mathrm{Hu}, \mathrm{Q}$. et al. (2012) 'Managing Employee Compliance with Information Security Policies: The Critical Role of Top Management and Organizational Culture', Decision Sciences Journal, 43(4), pp. 615660.

Istania, R. (2020) Kesamaan Wali Kota Surabaya dan Chicago dalam memimpin di tengah pandemic, Politik Masyarakat. Available at: https://theconversation.com/kesama an-wali-kota-surabaya-dan-chicagodalam-memimpin-di-tengahpandemi-134796 (Accessed: 8 May 2020).

Karakostas, A. and Zizzo, D. J. (2016) 'Compliance and the power of authority', Jouurnal of Economic Behavior \& Organization, 124, pp. 67-80. doi: 10.1016/j.jebo.2015.09.016.

Lestari, I. et al. (2015) 'A Review on Communication, Correction and Confirmation as Pressure for Nurse Compliance', International Journal of Academic Research, 7(3), pp. 2225. doi: 10.7813/2075.4124.2015/73/A.3.

Ministry of Administrative and Bureaucratic Reform (2020) Pencegahan Penyebaran Virus Covid-19 dengan Kerja di Rumah bagi ASN, Berita Terkini. Available at: https://www.menpan.go.id/site/berita 
-terkini/pencegahan-penyebaranvirus-covid-19-dengan-kerja-dirumah-bagi-asn (Accessed: 24 April 2020).

Ministry of Health of Republic of Indonesia (2020) Sekilas statistik korona, Sekilas statistik korona. Available at: https://covid-

monitoring.kemkes.go.id/ (Accessed: 8 May 2020).

Nicola, M. et al. (2020) 'The SocioEconomic Implications of the Coronavirus and COVID-19 Pandemic: A Review', International journal of surgery, 78, pp. 185-193. Available at: https://doi.org/10.1016/j.ijsu.2020.04. 018.

Nikoloski, K. (2015) 'Charismatic Leadership and Power: Using The Power of Charisma for Better Leadership In The Enterprises', Journal of Process ManagementNew Technologies, International, 3(2), pp. 18-27.

Shalihah, N. F. (2020) Total 1,9 Juta Pekerja Di-PHK dan Dirumahkan akibat Pandemi Virus Corona, Tren. Available at: https://www.kompas.com/tren/read/2 020/04/19/081000465/total-19-jutapekerja-di-phk-dan-dirumahkanakibat-pandemi-viruscorona?page=all (Accessed: 8 May 2020).

Supriyanto, S. et al. (2020) Kebijakan Kesehatan dan Analisis Kebijakan. Sidoarjo: Zifatama Jawara.

The Jakarta Post (2020) Leadership in Crisis, Editorial. Available at: https://www.thejakartapost.com/acad emia/2020/03/16/leadership-incrisis.html (Accessed: 8 May 2020).

Translation, O. of A. to D. C. S. for S. D. and (2020) Press Statement of President of the Republic of Indonesia on Government Policy to
Handle the Impacts of COVID-19 Pandemic, Thursday, 9 April 2020 at the Merdeka Palace, Jakarta, Cabinet Secretariat of the Republic of Indonesia. Available at: https://setkab.go.id/en/pressstatement-of-president-of-therepublic-of-indonesia-ongovernment-policy-to-handle-theimpacts-of-covid-19-pandemicthursday-9-april-2020-at-themerdeka-palace-jakarta/ (Accessed: 8 May 2020).

Wahyuni, N. C. (2020) Indonesia Currently Has Highest Covid-19 Mortality Rate in Asia, News. Available at: https://jakartaglobe.id/news/indonesi a-currently-has-highest-covid19mortality-rate-in-asia (Accessed: 8 May 2020).

Weske, U. et al. (2018) 'Using regulatory enforcement theory to explain compliance with quality and patient safety regulations: the case of internal audits', BMC health services research, 18(62), pp. 1-6. doi: 10.1186/s12913-018-2865-8.

World Health Organization (2020) Mental health and psychosocial considerations during the COVID-19 outbreak. Available at: https://www.who.int/docs/defaultsource/coronaviruse/mental-healthconsiderations.pdf (Accessed: 14 April 2020).

World Population Review (2020) Indonesia Population 2020, World Population Review. Available at: https://worldpopulationreview.com/co untries/indonesia-population/ (Accessed: 8 May 2020).

Zaenudin, A. (2019) Hasil Survei APJII: 64 Persen Penduduk Indonesia Gunakan Internet, Teknologi. Available at: https://tirto.id/hasilsurvei-apjii-64-persen-pendudukindonesia-gunakan-internet-dH4a 
(Accessed: 8 May 2020). 